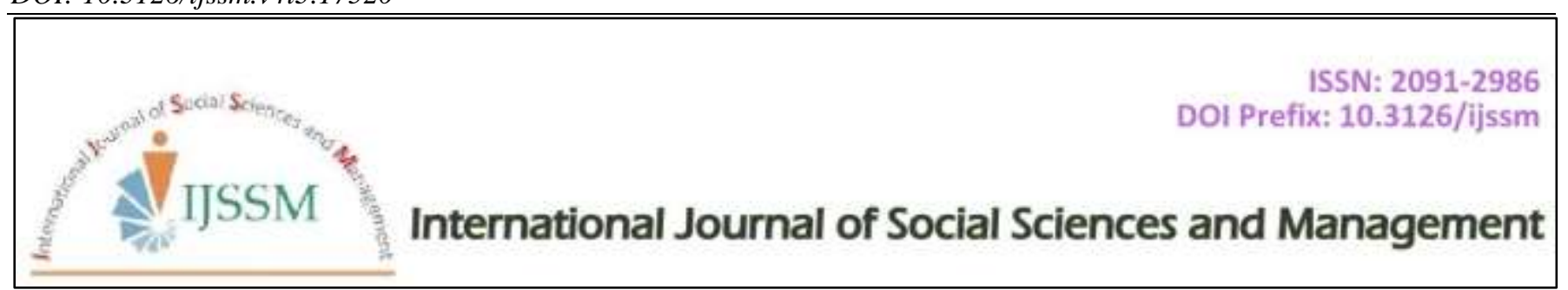

Research Article

\title{
Evaluation of the Impacts of Service Quality Dimensions on Patient/Customer Satisfaction: A Study of Private Hospitals in Nepal
}

\author{
Ramesh Neupane ${ }^{1 *}$ and Manju Devkota ${ }^{2}$ \\ ${ }^{1}$ University Village Thapathali, Kathmandu, Nepal \\ ${ }^{2}$ Save The Children, Western Field Office, Butwal, Nepal \\ *Corresponding author's email: rameshneupane47@yahoo.com
}

\begin{abstract}
The main purpose of this research is to examine the impacts of service quality dimensions on patient satisfaction as a study of private hospitals in Nepal. This research has also evaluated the perceptions of the patients about service quality offered by private hospitals and level of their satisfaction.

The research was conducted through influence of positivism philosophy and deductive approach. The two hypotheses were generated with the help of existing knowledge and literature related to service quality and customer/patient satisfaction. The formulated hypotheses were tested through primary data collection from the customers/patients of private hospitals in Nepal. The questionnaires survey was used to collect data in this study. Different five factors of SERVQUAL dimension and four factors of patient satisfaction: price, image, perceived quality and convenience were used to analyse service quality and patient satisfaction respectively. Samples of 490 patients from different 10 private hospitals which all are based on Kathmandu were considered in the study.

The results indicated that each dimension of service quality is positively correlated with patient satisfaction, and overall service quality and patient satisfaction has correlation coefficient of 0.719 which is significant at the 0.01 level. This implies that service quality and patient satisfaction are positively correlated with each other. The results demonstrated that service quality has strong positive impacts on patient satisfaction as regression analysis demonstrates that service quality has significant impacts on patient satisfaction as $\beta=0.719$ and $P=0.000$ which is less than 0.05 . Similarly, the results also indicated that private hospitals in Nepal are providing high level of service quality in the view of patients/customers; and there is high level of patient satisfaction at the private hospitals in Nepal.
\end{abstract}

Keywords: Service quality; patient satisfaction; service performance; patient's perceptions; private hospitals.

\section{Introduction}

Nepal has seen a lot of investments in health care sector. Many private companies including Chaudhari Groups have invested a lot in hospital sector. There is a strong presence of private hospitals in public healthcare in Nepal. The major private large hospitals include Norvic International Hospital, B\&B Hospital, OM Hospital, Neuro Hospital Bansbari, Kathmandu Medical College, Medicare Hospital, Manipal Medical College Pokhara, Grande International Hospital, Alka Hospital and so on. The expansion and success of private hospitals in Nepal, the ever growing need of quality healthcare service and the poor performance of public hospitals have provided immense opportunities for the private hospitals in Nepal. As there is a huge gap between the demand and supply in domestic healthcare services, the domestic market is large enough for private players to survive and make profits (Adhikari, 2013).

Hospitals operating in Nepal are required to focus their major efforts on rapidly excelling the quality of their services and satisfying the needs of their customer/patient in order to exist and drive success in the market. Because customer satisfaction is a key means to achieve the business ends, while service quality is the critical prerequisite for building, fostering and satisfying relationships with customers (Karatepe et al., 2005). High level of service quality obviously results in customer satisfaction, which enhance greater customer loyalty to the brand and finally helps companies to enhance their organisational performance (Lanka et al., 2009), to reap competitive advantage, and higher economic returns in the long term 
(Yeung and Ennew, 2004). It is very important for the hospitals to continuously measure quality of service against customer satisfaction so as to identify those areas that require improvement and to know whether customers/patients are satisfied or not. Furthermore, it is necessary for hospitals to discover the factors entirely influencing patient/customer satisfaction and to determine perceptions of customers on the determinants in order to provide high level of service quality to customers. This will boost their opportunities to differentiate them from competitors, attract new customers and retain their existing customers for the long terms (Gupta and Rokade, 2016).

Service quality is a fitness of use, conformance to requirements which focuses on customer's evaluation on the manner and outcome in which a service is delivered; or it is the difference between customer's perception on actual service performance and their expectations of firm's services (Zeithaml et al., 1996). The term customer/patient satisfaction is the degree to which customer feels gratified with product and service offered by organisation which is a tool for shaping customer's repurchase intention, customer loyalty, enhancing customer lifetime value, discouraging customer churn (Murti et al., 2013).

The hospital sector in Nepal is plagued by gloomy performance and facing tough competitions from the competitors. The public health care service in Nepal is very poor in terms of quality service and patient satisfaction. Therefore, private hospitals are predominantly required to focus on building trust, earning customer equity, providing high quality of service and high level of patient/customer satisfaction. For which, hospitals needs to have deep research and knowledge on service quality and they need to know that delivering high level of service quality is the only one mystery that can beat customer loyalty and satisfaction.

Hence, this research is aimed to analyse the factors of service quality in private hospital sector and their impact on the level of patient/customer satisfaction. This research has also established the relationship between the dimensions of service quality and patient/customer satisfaction. The findings will be useful for the future purpose of hospitals so as to boost and excel their services, and competitively meet customer/patient satisfaction, which can assist the company to achieve high level of performance and sustainable business growth. Thus, this research most importantly explores the knowledge on key determinant of service quality that positively influence patient/customer satisfaction and significance of service quality for the private hospitals in terms of competing with public hospitals in Nepal.

\section{Aims and Objectives of the Research}

This research aims to measure the impact of service quality dimensions on patient/customer satisfaction and discover the knowledge about how the different variables of service quality will have impact on determining the patient/customer satisfaction in the case of private hospitals in Nepal. The main objectives are as follows:

- To explore the service quality perceptions of the customers/patients in private hospital sector in Nepal.

- To investigate the perceptions of customers/patients about their satisfaction with private hospitals.

- To examine the impact of service quality on customer/patient satisfaction in hospital sector.

\section{Literature Review}

Service offering is crucial component of business function which is the way company communicate and deliver its products to customer and the tangibles it maintains for customers comfort, attraction and organisational performance. So, developing and offering excellent quality of service is undoubtedly an important input for meeting and exceeding customer expectation and needs which in turn positively influences loyalty behaviour of customers and enhances organisational performance and image, accelerates sales and growth of a company in the increasingly competitive market environment (Fisher, 2001). Thus, looking at the competitive environment, hospitals are required to develop their strategies to differentiate them from another that can only be achieved via the delivery of excellent quality of service. The high level of service quality determines customer satisfaction and customer satisfaction significantly leads companies to reap sustainable competitive advantage in the volatile market (Caruana, 2002).

\section{Service Quality}

Services are increasingly an indispensable portion of organisations nationally, regionally and globally, and considered as powerful tool for revenue streams. So, the success of service provider often starkly relies on the high level of relationship with the customers which determines customer loyalty and satisfaction that quality of service influences firm's outcomes such as increasing sales and profit (Lanka et al., 2009), improving customer relations, performance superiority, market share (Poretla and Thanassoulis, 2005), enhances customer loyalty and corporate image (Newman, 2001). In which, customer satisfaction and service quality are related to loyalty behaviour of customer via repurchase intentions (Caruana, 2002), and therefore delivery of higher quality of service to patients/customers is an inevitable for survival and success of the hospitals in today's dynamic and competitive environment. Service quality is a critical prerequisite for establishing, maintaining, sustaining, enhancing and satisfying relationship with valued customer. Thus, service quality is the extent to which service exceeds customer's 
earlier expectation thus it plays critical role to business success.

The burning truth realised in the firms today is that the perceived service/product quality getting significant importance and becoming the most crucial competitive factor in this high technology driven business world. As a result, many of the researchers and business intellectuals call service quality is the organisation's life giving blood and the most powerful weapon for competition (Neupane, 2014). Quality is the totality of characteristics and features of service or product that carries its ability to satisfy stated needs of customers (Kotler, 2003). Similarly, Quality is known as multi-dimensional phenomenon so that reaching the quality of service without distinguishing the major aspects of quality is far from possibility. Quality of service includes three output dimensions: service performance quality, technical quality and organization's mental picture (Gronroos, 1996).

Service quality is the difference between the perception of the service received and expectations of customer for the service encountered in which perception and expectation are the two central elements of service quality (Mosahab et al., 2010). It is assumed to be good quality of service if it consistently meets and exceeds expectations of customer (Parasuraman et al., 1985). The term service quality is perceived as the degree of discrepancy between normative expectation of customer for service and perception of customer on service performance. More precisely, service quality is the overall evaluation of firm's specific service resulting from the comparison between the firm's performances with the general expectation of customers about how companies should perform (Parasuraman et al., 1991). Quality of service is defined as the overall impression of the relative superiority or inferiority of the firms and its services on consumer's perception. It is also viewed as a form of attitude signifying long-term overall evaluation of organisational performance and a function of the discrepancy between performance and expectation along with the quality dimensions (Zeithaml et al., 1996). Service quality is cognitive and relativistic discrepancy between experience-based performance and norms regarding service benefits (Agus et al., 2007). The customers assess quality as high if perception of service exceeds customer's expectations; and as low when service performance does not meet expectations (Oliver, 1980). As a result, getting improved understanding of attitudes of customers facilitates to know how customers perceive quality of service in operation of hospitals. The prime aim of delivering quality service is to satisfy customers and measuring service quality is an efficient way to reign whether the services are bad or good. The service quality has three components called 3Ps as: physical facilities, personal behaviour and professional judgment (HaywoodFarmer, 1988).
In this way, majority of the literatures suggested that service quality is important factor to meet customer satisfaction, which is crucial especially in service driven sector like healthcare industry. It is assumed that higher the service quality, the more chance of meeting patient/customer satisfaction and the higher customer satisfaction leads more opportunities for the hospitals to beat the competition by achieving increased sale and market growth.

\section{Dimensions of Service Quality}

Over a time, to excel service quality, different quality measurement theories such as new public management (NPM) and total quality management (TQM) have been developed and practiced by many organizations around the world since the last decade. The main objective of new public management is to improve the delivery of quality service by adopting customer centric approach (Mwita, 2000). Similarly, neural network (NNs) and Data envelopment analysis (DEA) are the techniques developed to examine the relative efficiency of firms. Likewise, Parasaraman et al., (1991) conceptualized SERVQUAL model, which is most often applied model in the organizations today. This model assumes that the service quality can be measured as difference between customer's perceptions of given service delivery and customer's expectations of a given service delivery. According to this model, the evaluation of service quality is basically based on the process the firms deliver the service to the customers, if the level of service exceeds the expectation of customers then it is perceived as good quality of services.

Parasuraman et al. (1985) have identified ten useful elements required for customer's evaluation of service quality such as tangibles, reliability, responsiveness, credibility, communication, competence, security, courtesy etc. then, this model was modified and developed a generic instrument SERVQUAL, a service quality scale with fivefold dimensions includes tangibles, reliability, responsiveness, assurance and empathy as the lasting and reliable diagnostic tool for measuring service quality. This model has provided an inclusive conceptualisation to quality of service with an instrument to measure perceived service quality (Parasuraman et al., 1991). These are the key factors playing milestone role in meeting customer requirements, aspirations and expectations or customer satisfaction in the healthcare sector.

Tangibles: Tangibles refer to the appearance of equipment, physical facilities, written materials and personnel which are also major factors making customer to feel delighted and ownership towards the company's brand image (Parsauraman et al., 1991).

Reliability: Reliability is most important factor which is related to handling service problems of customers, performing services at the right time such as delivering services at the promised time and keeping error free records 
of each activity. Furthermore, reliability is all about accurate order fulfilment as accurate quote, accurate record, accurate in billing, and maintain service promise (Parsauraman et al., 1991).

Responsiveness: Responsiveness is another quality of service playing pivotal role to exceed customer's expectation, which is the readiness and willingness of employees to offer service encompasses timeliness of services (Kumar and Charles, 2010). It further includes understanding attention to customer's safety and problems in their transaction, individual attention given by employee, and convenient operating hours. These are vital in satisfying customer's expectation that responsiveness will delight customers and increase their likelihood for the organization.

Assurance: Assurance is courtesy and knowledge of employees and their ability to inspire confidence and trust (Parsauraman et al., 1991). In which, hospitals assurance means the friendly and polite staff/doctors/nurses, interior comfort, provision of financial advice, experienced and knowledgeable management team and eases of access to account information.

Empathy: Empathy is the individual attention and caring the organisation offers to its customers that involves giving individual attention to customers, and convenience opening hours (Perasuranman et al., 1985).

This model represents quality of service as the difference between customer expectations on offered services and their perceptions regarding to service received. The evaluation of service quality is based on the assessment of service outcomes and service delivery procedures by customers. The service quality which meets or exceeds the customers' anticipation is believed as good quality of service (Parsauraman et al., 1991).

Several arguments have been made regarding to the significance of this model. As argued by Cronin and Taylor (1992), the evaluation of service quality on the basis of gap between expectations and performance by SERVQUAL model is not sufficient. Similarly, as pointed by Babakus and Boller (1992), it has more explanatory power than the assessments gap between expectations and performances. A similar argument by Kang and James (2004) pointed that it has focused more on service delivery process than other aspects such as technical dimension. Furthermore, Chan et al. (2003) pointed that it is a popular tool for measuring service quality but the psychometric properties of the tool are not yet established. Similarly, Orwing et al. (1997) have failed to replicate these dimensions and suggested that these dimensions represent only one factor rather than five. Conversely, Buttle (1996) pointed that SERVQUAL model is applied by various researchers to measure service quality in many companies like banking, retailing, telecommunications, restaurants, educations, hospitals and hotels. Similarly, a research carried out by Ladhari (2009), recommended that SERVQUAL is a good scale to use and measure service quality in specific organisations. In this regard, service quality in private hospitals in Nepal is measured by this framework.

\section{Patient/Customer Satisfaction}

Patient/customer satisfaction refers the psychological state of patient involves their positive or negative feelings or attitudes toward their experience and some specific aspects in the service encounter (Chang et al., 2013). It is a key to long-term success of business, which is major factor in shaping customer's intentions for future repurchase. It provides essential link between post purchase phenomena and cumulative purchase in relation to brand loyalty, repeat purchase, attitude change (Churchill and Surprenant, 1982). It is argued that satisfied customers would prefer to share their good experience to their friends and relatives so they will work as referral thorough words-of-mouth, which motivates even others to make their purchase desires with the company (Mittal and Kamakura, 2001). Satisfaction is the difference between performance and expectation but still some argue that there is difference between satisfaction and quality. As Parasuraman et al. (1991) stated that satisfaction is a result of experience or decision made after service experiences whereas quality is something already ready for delivery to customers.

Satisfaction is a feeling of pleasure as a result of achieving something, and an action of fulfilling desire, expectation and need (Magesh, 2010). Customers are always selective so they compare their expectations about a specific services or products and benefits they achieve from the service. According to Kotler and Armstrong (2012), satisfaction is an individual's feeling of disappointment or pleasure resulting from the comparison of expectation in reference to perceived performance of product or services. Similarly, Zeithmal et al. (2009) stated that satisfaction is the measure of capability of service/product to meet customer's expectation. In which, Razak et al. (2007) also argued that satisfaction is the result of customer's measurement of a specific experience linked with the service provider. So, if customers are satisfied with organisation's services, then customers become loyal to them and as result customer will be retained with the company that provides positive results for the organisation because the customer retention also means increasing customer base, higher market share, higher sales and profit (Karatepe et al., 2005).

Satisfaction is the terms related to a particular transaction means the difference between perceived service and predicted service in contrast with attitudes that are less situation oriented and more enduring (Zeithaml et al., 2009). Basically there two general conceptualization of customer satisfactions "cumulative satisfaction" and "transaction specific satisfaction” (Boulding et al., 1993. 
Cumulative satisfaction is defined as the overall customer's evaluation of consumption experience and transactions specific satisfaction refers to evaluation of customers on their reactions and experience to particular service encounter (Yi and La, 2004).

According to Hill et al. (2007), “Customer satisfaction is a measure of how your organisation's total product performs in relation to a set of customer requirements". Obviously, the client's vision towards any company's performance is an opinion. The customer's view about their satisfaction is in their minds and they may or may not follow the situational reality. So, measurement of customer satisfaction is all about quantifying how customer remarks the performance of the service/product providing organisation.

Thus, patient/customer satisfaction is a psychological state involves their positive or negative feelings or attitudes toward their experience with the service encounter. Satisfaction captures the provision of services/goods that fulfil the patients/customers' expectations in terms of service and quality in association to price paid.

\section{Relationship between Service Quality and Patient/Customer Satisfaction}

Service quality and customer satisfaction have cause and effect relationship to each other and playing decisive role for existence and success of business in today's high technology led competitive market. In terms of their relationship, Oliver (1993) asserted that quality of service is antecedent to customer satisfaction irrespective of whether the constructs are transaction specific or cumulative. Whereas, service quality emphasises on specific dimension of service unlike this, satisfaction is a broader term however the factors such as product directly or indirectly affect customer's satisfaction and perceived service quality is an indispensable component of determining customer satisfaction (Zeithaml et al., 2009). Service quality is a concentrated evaluation reflecting the customer's perception of assurance, empathy, reliability and responsiveness while satisfaction is inclusive and influenced by perception of product's quality and price, service quality and personal and situational factors (Wilson et al., 2008).

In terms of relationship between service quality and customer satisfaction, they have certain things in common but service quality emphasizes particularly on dimensions of service whereas satisfaction is broader concept (Wilson et al., 2008). As the service quality and satisfaction are the antecedents of behavioural intentions of customers that customer satisfaction does not by itself creates lifetime value for customer (Appiah-Adu, 1999). According to Pouragha and Zarei (2016), service quality dimensions have significant impacts on outpatient satisfaction. Similarly, another study by Alghamdi (2014) found statistically significant impacts of service quality factors on patient satisfaction. They have complementary relationship between satisfaction and service quality and positive linear triple effects relationship with organizational performance that satisfaction cannot be achieved without the delivery of quality of service and without customer satisfaction; business cannot realise its success.

Number of past studies demonstrated that service quality and satisfaction are interrelated with each other. A study by Andaleeb (2001) found that service quality has significant impacts on patient satisfaction in the hospitals in a developing country. Similarly, Agarwal and Singh (2016) also found significant relationships between service quality dimension and patient satisfaction. Another study by Chang et al. (2013) also found significant relationships between service quality and patient satisfaction in interpersonal based medical services encounters. The results stated that perceptions of interpersonal-based medical service encounters positively influence service quality and patient satisfaction. Perception of service quality among patients positively influences their trust. Perception of trust among patients positively influences their satisfaction.

It has proved that service quality and customer satisfaction are positively correlated from their definitions to their relationship in many practical aspects of business that service quality determines the customer satisfaction in different level. If perceived service quality is high then it can increase customer satisfaction index. Thus, customer satisfaction is often relied upon the level of service quality offered by the companies (Parasuraman et al., 1995). Thus, based on the above review, we conclude that there is indispensable and cause and effect linkage between the two elements of business; the five dimension of SERVQUL scales are the key element of service quality and these factors effectively influence customer satisfaction. Thus, the following conceptual framework is developed in this investigation.

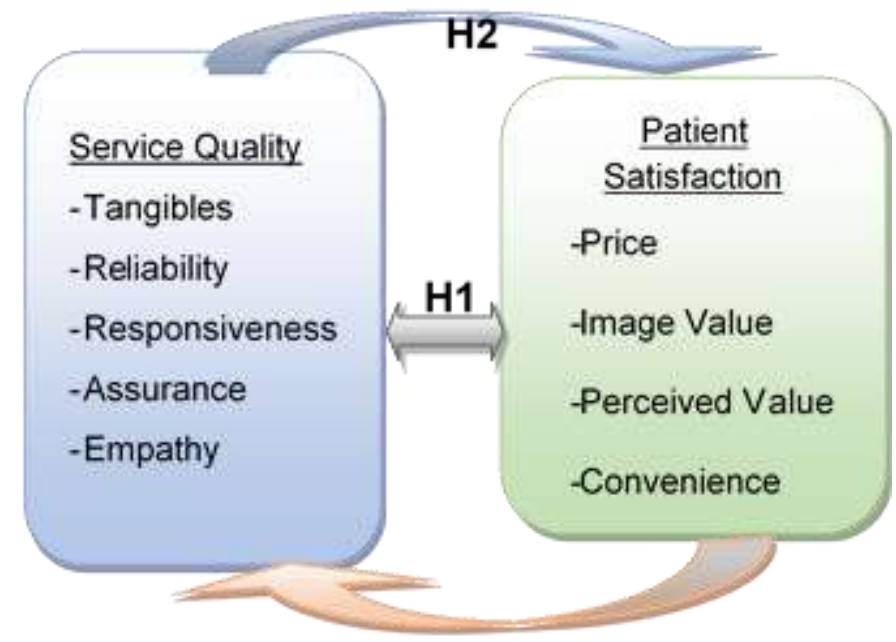

Fig. 1: Conceptual framework of the research 
On the basis of above conceptual framework the following hypotheses are generated.

H1: The service quality dimensions and patient satisfaction are positively correlated in hospital sector.

$\mathrm{H} 2$ : Service quality has significant positive impacts on patient satisfaction in hospital sector.

\section{Research Methodology}

This research was conducted using quantitative techniques to analyse the primary data in order to test hypotheses of this research. It has used self-administered five point rating scale questionnaires under survey strategy to gather primary data for the study in which judgemental sampling is applied to get the sizeable sample population. The obtained data are tested and analysed using statistical tools such as regression analysis, correlation with the use of the SPSS software.

This study has chosen positivism philosophy and deductive approach because it emphasises on quantitative method and scientific tools in exploring social reality instead of viewing knowledge is personal experience rather than acquired by objective ways (Wilson, 2010). Following this philosophical assumption, it has developed two hypotheses based on the existing theories, and applied scientific techniques and tools to achieve the data to test hypothesis and make conclusion of the research.

\section{Data Collection}

In this research, primary data was used to test hypothesis and to fulfil research objectives. To obtain primary data, questionnaire survey technique was applied. This research adopted survey strategy for obtaining the desired data from the patients of the private hospitals in Nepal because it eases the data collection process; and also facilitates quantitative data analysis using inferential and descriptive statistics. Moreover, it is cost effective and facilitates powerful tool of questionnaire to gather the opinion of individuals from the large sample, and easy to use with less understanding and knowledge (Saunders et al., 2009).

So, primary data was collected in this study via the use of self-administered questionnaire that are easy for interpretation, test and analysis applying statistical tools and draw research concussion. All the questionnaires were formulated in five point rating scale in which 1 stands for strongly disagree and 5 stands for strongly agree.

In this study, total of 750 set of questionnaires were prepared and distributed to the patients at the exit corner of different 10 large private hospitals based on Kathmandu Nepal. The patient and their relatives were requested to fill the questionnaires, and then the answered set of questionnaires was collected instantly. Out of 750 set of questionnaires distributed, it was obtained 490 set of usable answered questionnaires. So, the response rate of the questionnaires was $65.33 \%$. The technique of judgement sampling was used to get respondents in this study.

\section{Data Analysis}

The collected primary data were analysed with the help of statistical tools and techniques using SPSS 20. Mainly, the relationships between service quality dimension and patient satisfaction is examined using correlation coefficient. Similarly, the impact of service quality dimension on patient satisfaction was examined through regression analysis. Here, the factors of service quality are predictor/independent variables and patient/customer satisfaction is dependent variable.

\section{Data Analysis, Findings and Discussion}

\section{Demographic Results}

The current survey included 260 males and 230 female patients out of the sample of 490 people. This means there were $53 \%$ male and $47 \%$ female in the survey. The following table 1 shows the education level of the participants in the current survey.

Table 1: Education Level of the Participants

\begin{tabular}{|l|l|l|}
\hline Education Level & Frequency & Percentage \\
\hline Less than High School & 126 & $25.71 \%$ \\
\hline High School & 152 & $31.02 \%$ \\
\hline Bachelors & 120 & $24.49 \%$ \\
\hline Masters & 80 & $16.33 \%$ \\
\hline Above Masters & 12 & $2.45 \%$ \\
\hline Total & 490 & $100 \%$ \\
\hline
\end{tabular}

The Table 1 shows that the greatest number of patients who have taken part in the survey has high school level qualification while the smallest number of patients has above master's degree qualification. The percentage of the customers having different qualification is represented in the following Fig. 2.

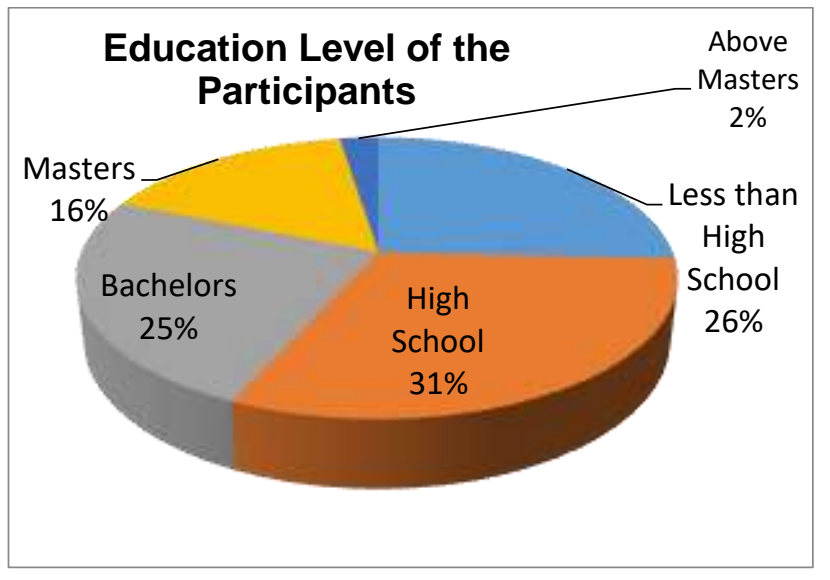

Fig. 2: Education Level of the Patients

The Fig. 2 shows that highest percentage of the customers of private hospitals who have taken part in the current survey have high school level qualification which is $31.0 \%$ while the lowest percentage of customers have above 
master's degree qualification which is just about $2.0 \%$ of the total. Similarly, $26.0 \%$ customers have less than high school level qualification, $25.0 \%$ have bachelor's degree qualification and $16.0 \%$ customers have master's degree qualification. This shows that the patients/customers of private hospitals in Nepal are academically diverge in different qualifications.

Table 2 shows the willingness of patient/customers to use same private hospitals for the next two years.

Table 2: Willingness of customers to use same hospital for next two years

\begin{tabular}{|l|l|l|}
\hline Construct & Frequency & Percentage \\
\hline Yes & 240 & $48.98 \%$ \\
\hline May be & 210 & $42.86 \%$ \\
\hline No & 40 & $8.16 \%$ \\
\hline Total & 490 & $100 \%$ \\
\hline
\end{tabular}

The Table 2 demonstrates that the greatest number of customers said they are willing to continue the same hospital for the next two years whereas the lowest number of customers said they are not willing to continue this hospital for the next two years. The respective percentages are shown in the following Fig. 3.

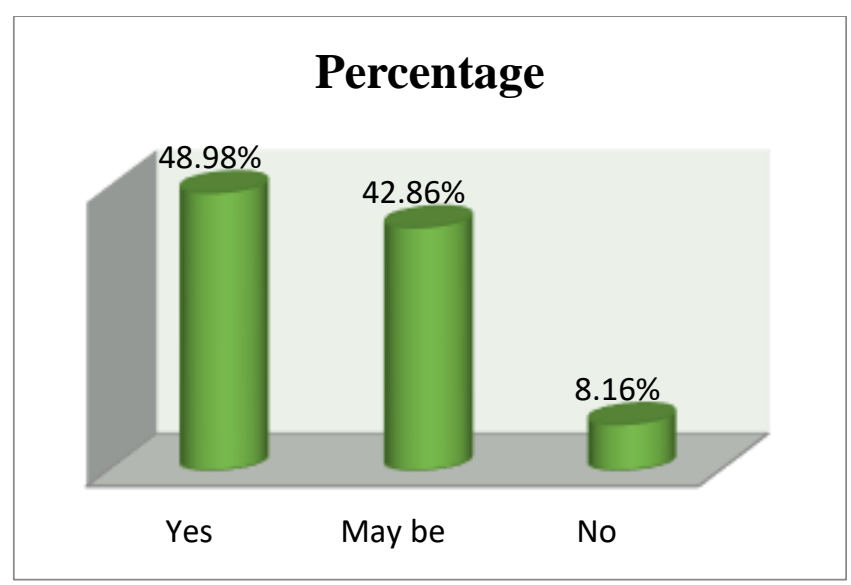

Fig. 3: Willingness of customers to use same hospital for next two years

The above bar diagram shows that $48.98 \%$ customers really have willingness to continue to the same hospital for next two years. The lowest of $8.16 \%$ of customers said that they have no willingness to continue the same hospital for the next two years. Similarly, $42.86 \%$ customers replied that they may continue same hospital for the next two years. When combined 'yes' and 'may be' it is about $91.84 \%$ patients/customers have willingness to use the same hospital service for the next two years, which is a good news for the private hospitals in Nepal. This means, there is high level of patient/customer retention at the private hospitals in Nepal.

\section{Assessment of Service Quality Perceptions of the Patient}

The service quality perceptions of the patients in private hospitals is evaluated through arithmetic mean scores of the items for the factors of SERVQUAL dimension obtained in the rating scale of 1 to 5 . The lowest point 1 represents 'strongly disagree' and the optimum point 5 in the scale represents 'strongly agree'. The arithmetic means of the scores for the dimension of service quality are shown in table 3 .

Table 3: Arithmetic Mean of the Factors of Service Quality

\begin{tabular}{|l|l|}
\hline Factors & Arithmetic Mean \\
\hline Tangible & 4.06 \\
\hline Reliability & 4.11 \\
\hline Responsiveness & 4.09 \\
\hline Assurance & 4.24 \\
\hline Empathy & 4.20 \\
\hline Overall Service Quality & 4.14 \\
\hline
\end{tabular}

The Table 3 shows that all the factors of service quality have arithmetic mean of the scores obtained in the five point rating scale is more than 4.06 out of 5 . The highest value of mean score is 4.24 from assurance factors and the lowest mean score is 4.06 from tangible item. Similarly, the mean of reliability is 4.11 , mean of responsiveness is 4.09 , and mean score of empathy is 4.20 . This means, each and every components of service quality has mean score more than neutral value 3 and tends to optimum value five.

Thus, the evaluation of mean scores for the factor of service quality implies that all the components of service quality has mean score more than 4.06 out of 5; and the overall service quality has mean scores 4.14 which represents $82.8 \%$ indicates that private hospitals in Nepal are providing high level of service quality in the view of patients/customers.

\section{Evaluation of Patient Satisfaction in Private Hospitals in Nepal}

The patient satisfaction in private hospitals in Nepal is examined by using four components: price, perceived value, image quality and convenience. The extent of patient satisfaction is also analysed through mean of the scores obtained in the five point rating scale provided by the survey participants. The mean scores are shown in table 4 .

Table 4: Mean Scores for the Components of Patient Satisfaction

\begin{tabular}{|l|l|}
\hline Constructs & Arithmetic Mean \\
\hline Price & 4.00 \\
\hline Perceived Value & 4.00 \\
\hline Image & 4.21 \\
\hline Convenience & 4.07 \\
\hline Overall patient Satisfaction & 4.06 \\
\hline
\end{tabular}

The above table illustrates that each factor of patient/customer satisfaction has arithmetic mean score more than 4.00 obtained in the five point rating scale. The greatest value of mean is 4.21 from image of the corresponding hospital and smallest value of mean is 4.00 
from perceived value and price for the service offered by private hospitals in Nepal. The mean score for convenience is 4.07 out of 5 .

Thus, assessment of mean scores for the components of patient satisfaction shows that each factor of patient satisfaction has mean score more than 4.00 out of five; and overall patient satisfaction has mean score of 4.06 which is about $81.2 \%$ indicating that there is high level of patient satisfaction at the private hospitals in Nepal.

\section{Evaluation of Impacts of Service Quality on Patient Satisfaction}

The relationships between the dimensions of service quality and patient satisfaction are examined through correlation analysis between the factors of service quality and patient satisfaction. The inter-correlations between service quality dimensions and patient satisfaction are shown in Table 5.

The correlation Table 5 shows that each factor of service quality is positively correlated to patient satisfaction. The correlation between tangibles and patient satisfaction is 0.647, reliability and patient satisfaction is 0.740 , responsiveness and patient satisfaction is 0.725 , assurance and patient satisfaction is 0.581 , empathy and patient satisfaction is 0.446 which are all strongly positive as well as significant at the 0.01 level.
Similarly, the impact of service quality on patient satisfaction is assessed through regression analysis. The coefficient of regression is presented in Table 6 .

In the regression model (Table 6 ), the value of beta $(\beta)=$ 0.719 represents simple correlation coefficient between the two factors: service quality and patient satisfaction. The value of $p=0.00$ which is far less than 0.05 indicates that there is significant impacts of service quality on patient satisfaction.

Regression Equation is therefore:

Patient Satisfaction $=1.923+0.518$ (Service Quality)

Thus, the evaluation of inter-correlation between the factors of service quality and patient satisfaction shows that each dimension of service quality is positively correlated with patient satisfaction, and overall service quality and patient satisfaction has correlation coefficient of 0.719 which is also significant at the 0.01 level. Regression analysis demonstrates that service quality has significant impacts on customer satisfaction as $\beta=0.719$ and $P=0.000$ that is less than 0.05 . This implies that service quality and patient satisfaction are positively correlated with each other; and service quality has significant impacts on patient satisfaction.

Table 5: Correlation between Service Quality Factors and Patient Satisfaction

\begin{tabular}{|c|c|c|c|c|c|c|c|}
\hline \multicolumn{8}{|c|}{ Correlations } \\
\hline & $\begin{array}{l}\frac{\tilde{\theta}}{0} \\
\frac{0}{00} \\
\tilde{E} \\
\tilde{E}\end{array}$ & 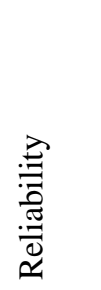 & 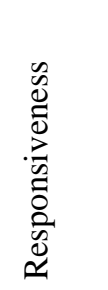 & 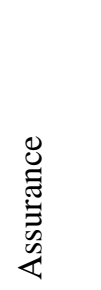 & 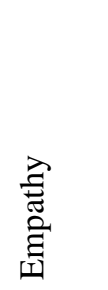 & 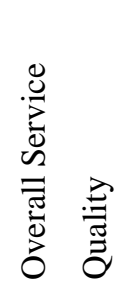 & 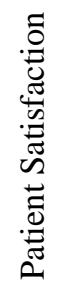 \\
\hline Tangibles & 1 & & & & & & \\
\hline Reliability & $.915^{* *}$ & 1 & & & & & \\
\hline Responsiveness & $.742^{* *}$ & $.876^{* *}$ & 1 & & & & \\
\hline Assurance & $.574^{* *}$ & $.711^{* *}$ & $.897^{* *}$ & 1 & & & \\
\hline Empathy & $.405^{* *}$ & $.562^{* *}$ & $.760^{* *}$ & $.897^{* *}$ & 1 & & \\
\hline Overall Service Quality & $.838^{* *}$ & $.928^{* *}$ & $.960^{* *}$ & $.905^{* *}$ & $.801^{* *}$ & 1 & \\
\hline Patient Satisfaction & $.647^{* *}$ & $.740^{* *}$ & $.725^{* *}$ & $.581^{* *}$ & $.446^{* *}$ & $.719^{* *}$ & 1 \\
\hline
\end{tabular}

Table 6: Coefficient of Regression

\begin{tabular}{|l|l|r|r|r|r|r|}
\hline \multirow{2}{*}{ Model } & \multicolumn{2}{|c|}{ Unstandardized Coefficients } & Standardized Coefficients & \multirow{2}{*}{ T } & \multirow{2}{*}{ Sig. (P) } \\
\cline { 2 - 6 } \multicolumn{2}{l|}{1} & B & Std. Error & Beta & \\
\hline \multirow{2}{*}{1} & 1.923 & .230 & & 8.363 & .000 \\
\cline { 2 - 6 } & Service Quality & .518 & .055 & 0.719 & 9.364 & .000 \\
\hline
\end{tabular}




\section{Discussion of the Main Findings}

This study has examined the impact of service quality on patient satisfaction in the private hospitals in Nepal. It has also examined the service quality perception of the patients/customers of the private hospitals as well as the level of patient satisfaction in the private hospitals in Nepal.

The evaluation of mean scores for the factor of service quality implies that all the components of service quality has mean score more than 4.06 out of 5 ; and the overall service quality has mean scores 4.14 which represents $82.8 \%$ indicates that private hospitals in Nepal are providing high level of service quality in the view of patients/customers. This means patients/customers are very happy with the services offered by private hospitals in Nepal.

Similarly, the assessment of mean scores for the components of patient satisfaction shows that each factor of patient satisfaction has mean score more than 4.00 out of five; and overall patient satisfaction has mean score of 4.06 which is about $81.2 \%$ indicating that there is high level of patient satisfaction at the private hospitals in Nepal. This precisely means that the private hospitals have prominent roles in healthcare sector in Nepal which are offering excellent level of service quality to fulfil the expectation of the private patient.

Similarly, the evaluation of inter-correlation between the factors of service quality and patient satisfaction shows that each dimension of service quality is positively correlated with patient satisfaction, and overall service quality and patient satisfaction has correlation coefficient of 0.719 which is also significant at the 0.01 level. This implies that service quality and patient satisfaction are positively correlated with each other. These findings support our first hypothesis H1: The service quality dimensions and patient satisfaction are positively correlated in hospital sector, and thus $\mathrm{H} 1$ is accepted. The findings are consistent with many previous studies. Oliver (1993) asserted that quality of service is antecedent to customer satisfaction irrespective of whether the constructs are transaction specific or cumulative. Whereas, service quality emphasises on specific dimension of service unlike this, satisfaction is a broader term however the factors such as product directly or indirectly affect customer's satisfaction and perceived service quality is an indispensable component of determining customer satisfaction (Zeithaml et al., 2009). Similarly, a research by Agarwal and Singh (2016) found significant relationships between service quality dimension and patient satisfaction. Another study by Chang et al. (2013) also found significant links between service quality and patient satisfaction in interpersonal -based medical services encounters.
Next, regression analysis demonstrates that service quality has significant impacts on customer satisfaction as $\beta=$ 0.719 and $\mathrm{P}=0.000$ that is less than 0.05 . This means, service quality has significant impacts on patient satisfaction. These findings support H2: Service quality has significant positive impacts on patient satisfaction in hospital sector, and thus $\mathrm{H} 2$ is also accepted. This result is consistent with many earlier studies in other settings and other industries. A study by Andaleeb (2001) found that service quality has significant impacts on patient satisfaction in the hospitals in a developing country. Similarly, according to Pouragha and Zarei (2016), service quality dimensions have significant impacts on outpatient satisfaction. Similarly, another study by Alghamdi (2014) found statistically significant impacts of service quality factors on patient satisfaction. Likewise, as Wilson et al. (2008) asserted that service quality is very important to provide higher level of customer satisfaction. Thus, the result of this research is consistent with many earlier studies.

\section{Conclusion}

This empirical research investigated the impacts of service quality on patient satisfaction in the private hospitals in Nepal. This research has also evaluated the perceptions of the customers about service quality in private hospitals and extent of their satisfaction.

The research was conducted through influence of positivism philosophy and deductive approach. The two hypotheses were generated with the help of existing knowledge and literature related to service quality and patient/customer satisfaction. The formulated hypotheses were tested through primary data collection from the patient/customers of different 10 private hospitals in Nepal based on Kathmandu. The questionnaires survey was used to collect data in this study. Different five factors of SERVQUAL model and four factors of patient/customer satisfaction: price, image, perceived quality and convenience are used to analyse service quality and customer satisfaction respectively. A sample of 490 patients/customers is considered in the study. The result of the study was obtained from the evaluation of primary data with the help of statistical tools using SPSS 20.

The evaluation of mean scores for the factor of service quality implies that all the components of service quality has mean score more than 4.06 out of 5 ; and the overall service quality has mean scores 4.14 which represents $82.8 \%$ indicates that private hospitals in Nepal are providing high level of service quality in the view of patients/customers. Similarly, the assessment of mean scores for the components of patient satisfaction shows that each factor of patient satisfaction has mean score more than 4.00 out of five; and overall patient satisfaction has mean 
score of 4.06 which is about $81.2 \%$ indicating that there is high level of patient satisfaction at the private hospitals in Nepal.

The evaluation of inter-correlation between the factors of service quality and patient satisfaction shows that each dimension of service quality is positively correlated with patient satisfaction, and overall service quality and patient satisfaction has correlation coefficient of 0.719 which is significant at the 0.01 level. Similarly, regression analysis demonstrates that service quality has significant impacts on customer satisfaction as $\beta=0.719$ and $\mathrm{P}=0.000$ that is less than 0.05. This implies that service quality and patient satisfaction are positively correlated with each other; and service quality has significant impacts on patient satisfaction.

\section{Recommendations}

The results show that around $51 \%$ patients are not sure about continuing the services of private hospitals for next two years. This is a large percentage of customers who have uncertainty. However, this percentage is obtained by adding the percentage of customers who said 'may be' and 'no'. The management of private hospitals should keep their eyes in this issue how a large portion of their patients/customers have no certainty to continue the hospital services from the private hospitals. It is recommended to investigate the reasons by conducting extensive patient survey and resolve the issue if there are any.

The private hospitals should pay attention of any complaint from the patients, and resolve immediately in order to further improve patient satisfaction level. The private hospitals can further focus on employee training and development for the enhancement of quality of service by particularly focusing on how to enhance patient service.

There are many issues about customer care in some private hospitals in Nepal. The management should be strictly focused on providing excellent level of customer care in order to be competitive in the market.

Private hospitals should not always be concentrated on returns as this sector is very sensitive and linked to wellbeing of the people. So, it is recommended that private hospitals should offer some free treatment facilities for the minority groups, poor people, and elderly population.

\section{Limitations and Further Research}

The main limitations of this research are: small sample of 490 patients from just 10 private hospitals based on Kathmandu only; use of quantitative data analysis techniques only rather than using mixed methods; and use of questionnaires survey with fixed alternatives for data collection from the patients, in which patients have to choose answer from the alternatives provided in the questionnaires, and so they may not provide answer freely in the survey.
So, it is suggested to conduct an extensive research with large sample survey with taking many hospitals from different parts of Nepal in order to test the validity of current research findings. The further researcher can use different models of service quality as this SERVQUAL model may have some limitations. Similarly, the further researcher can identify more factors of patient/customer satisfaction specially associated to hospital sector.

\section{References}

Adhikari S (2013) Health is Wealth: The Rise of Private Hospitals in Nepal. New Business Age, online available at: http://www.newbusinessage.com/MagazineArticles/view/ 490 [Accessed on 2017-05-10].

Agarwal A and Singh MR (2016) Service Quality and Patient Satisfaction: An Exploratory Study of Pathology Laboratories in Jaipur. Hospital Topics 94(2): 23-32.

Agus A, Barker S, and Kandampully J (2007) An exploratory study of service quality in the Malaysian public service sector. International Journal of Quality \& Reliability Management 24(2): 177-190.

Alghamdi FS (2014) The impacts of service quality perceptions on patient satisfaction in Government Hospitals in Southern Saudi Arabia. Saudi Medical Journal 35 (10): 1271-1273.

Andaleeb SS (2001) Service quality perceptions and patient satisfaction: a study of hospitals in a developing country. Social Science and Management 52 (9): 1359-70.

Appiah-Adu K (1999) Marketing Effectiveness and Customer Retention in the Service Sector. The Service Industries Journal 19(3): 26-41.

Babakus E and Boller GW (1992) An empirical assessment of the SERVQUAL scale. Journal of Business Research 24 (3): 253-268.

Beiskke B (2007) Research method: limitation and uses of interviews, questionnaires and case studies. Berlin: Smith and John publication.

Buttle F (1996) SERVQUAL: review, critique, research agenda. European Journal of Marketing 30 (1): .8-32.

Caruana A (2002) Service loyalty: The effects of service quality and the mediating role of customer satisfaction. European Journal of Marketing 36 (7/8): 811-828.

Chan C, Entrekin L and Anderson C (2003) Psychometric assessment of the perception of service quality. Research and Practice in Human Resource Management 11 (1): 65 -74 .

Chang CS, Chen SY and Lan, YT (2013) Service quality, trust, and patient satisfaction in interpersonal - based medical service encounters. BMC Health Service Research DOI: 10.1186/1472-6963-13-22.

Churchill GA Jr and Surprenant C (1982) An Investigation into the Determinants of Customer Satisfaction. Journal of Marketing Research 19 (November): 491 -504. 
Cronin JJ and and Taylor S (1992) Measuring Service Quality - A Re-examination and Extension. Journal of Marketing 56: 55-68.

Fisher A (2001) Keys of winning the battle for customer satisfaction. Financial marketing journal 5 (1): 45-56.

Grönroos C (1996) Relationship marketing: strategic and tactical implications. Management Decision 34 (3): 5-14.

Gupta KS and Rokade V (2016) Importance of Quality in Health Care Sector: A Review. Journal of Health Management 18(1): $84-94$.

Haywood- Farmer J (1988) A Conceptual Model of Service Quality. International Journal of Operations \& Production Management 8 (6): 19-29.

Kang G and James J (2004) Service quality dimensions: an examination of Grönroos's service quality model. Managing Service Quality: An International Journal 14 (4): 266-277.

Karatepe O, Yavas U and Babakus E (2005) Measuring Service Quality of Banks: Scale Development and Validation. Journal of Retailing and Consumer Services 12(5): 373383.

Kotler P (2003) Marketing Management (11 $1^{\text {th }}$ ed.). New Jersey: Prentice-Hall, Englewood Cliffs.

Kotler P and Armstrong G (2012) Marketing Principles (14 ${ }^{\text {th }}$ ed.). USA: Pearson education Pvt. Ltd.

Kumar M, and Charles V (2010) Evaluation of major factors in delivery of service quality of retail banks. Journal of internal reliability and quality management 25 (2): 210245.

Ladhari R (2009) A review of twenty years of SERVQUAL research. International Journal of Quality and Service Sciences 1 (2): 172-198.

Lanka U, Suar D, and Mohapatara PKJ (2009) Service Quality, Customer Satisfaction and Customer Loyalty in Indian Commercial Banks. The Journal of Entrepreneur 18(1): 47-64.

Laroche M, Ueltschy LC, Abe S, Cleveland M and Yannopoulos $P$ (2004) Service quality perceptions and customer satisfaction: Evaluating the role of culture. Journal of International Marketing 12 (3): 58-85.

Magesh R (2010) A Study on Quality of Service as a Tool for Enhancement of Customer Satisfaction in Banks. Global Journal of Finance and Management 2: 123-133.

Mittal V, and Kamakura W (2001) Repurchase intent, satisfaction and repurchase behaviour: investigating the effect of customer. Marketing research journal 35 (1): 124-145.

Mosahab R, Mahamad O and Ramayah T (2010) Service Quality, Customer Satisfaction And Loyalty: A Test o Mediation. International Journal of Business and Management 3(4): 80-85.

Muhondwa EPY, Leshabari MT, Mwangu M, Mbembati N and Ezekiel MJ (2008) Patient Satisfaction at the Muhimbili
National Hospital in Dar Es Salaam, Tanzania. East African Journal of Public Health 5(2): 67-73.

Murti A, Deshpande A and Srivastava N (2013) Service Quality, Customer (Patient) Satisfaction and Behavioural Intention in Health Care Services: Exploring the Indian Perspective. Journal of Health Management 15 (1): 29-44.

Mwita JI (2000) Performance management model: A systemsbased approach to public service quality. International Journal of Public Sector Management 13 (1): 19-37.

Neupane R (2014) Relationships between customer satisfaction and business performance in Lloyds bank UK: A Case Study. International Journal of Social Science and Management 1 (2): 78-85.

Newman K (2001) Interrogating SERVQUAL: a critical assessment of service quality measurement in a high street retail bank. International Journal of Bank Marketing 19(3): 126-139.

Oliver RL (1980) A cognitive model of the antecedents and consequences of satisfaction decisions. Journal of Marketing Research XVII (November): 460-69.

Oliver RL (1993) A conceptual model of service quality and service satisfaction: compatible goals, different concepts. Advances in Service Marketing and Management 2: $65-$ 85 .

Orwing RA, Pearson J and Cochran D (1997) An empirical investigation into validity of SERVQUAL in the public sector. Public Administration Quarterly 21 (1): 54-68.

Parasuraman A, Zheitmal VA and Berry LL (1988) SERVQUAL: a multipleitem scale for measuring consumer perceptions of service quality. Journal of Retailing 64(1):12-40.

Parasuraman A, Berry L and Zeithaml VA (1985) A Conceptual Model of Service Quality and Its Implication for Future Research. Journal of Marketing 49(4): 41-50.

Parasuraman A, Berry LL and Zeithaml VA (1991) Understanding Customer Expectations of Service. Sloan Management Review 32 (3): 39-48.

Portela MCAS and Thanassoulis E (2005) Profitability of a sample of Portuguese bank branches and its decomposition into technical and allocative components. European Journal of Operational Research 162(3): 850-866.

Pouragha B and Zarei E (2016) The Effect of Outpatient Service Quality on Patient Satisfaction in Teaching Hospitals in Iran. Materia Socio Media 28 (1): 21-25.

Razak MRA, Chong SC and Lin B (2007) Service quality of a local Malaysian bank: Customers' expectations, perceptions, satisfaction and loyal. International Journal of Services and Standards 3(1):18-38.

Saunders, M, Lewis, P and Thornhill, A. (2009) Research Methods for Business Students, (5 ${ }^{\text {th }}$ ed.). Essex, England: Pearson Education Limited.

Seth S and Vrat Pl (2005) A review of service quality models. Journal of international reliability and quality management 20 (2): 540-560. 
Sureshchandar GS, Rajendran C and Anantharaman RN (2002) The relationship between service quality and customer satisfaction - a factor approach. Journal of Services Marketing 14(4): 363-379.

Sureshchandar S, and Ananthraman N (2003) Perception of customer on service quality: Analysis approach for confirmatory factor. International journal of marketing $\mathbf{1 5}$ (2): $34-56$.

William B, Kalra A, Staelin R and Zeithaml VA (1993) A Dynamic Process Model of Service Quality: From Expectations to Behavioral Intentions, Journal of Marketing Research 30 (1): 7-27.

Wilson A, Zeithaml V, Bitner M and Gremier D (2008) Services marketing: integrating customer focus across the firm, First European Edition. UK: McGraw Hill.

Wilson J (2010) Essentials of Business Research: A Guide to Doing Your Research Project. London: Sage.

Yeung $\mathrm{CH}$ and Ennew T (2004) A reconceptualisation of the satisfaction service performance thesis. Journal of Marketing Services 17: 20-34.
Yi Y and La S (2004) What Influences the Relationship between Customer Satisfaction and Repurchase Intention? Investigating the Effects of Adjusted Expectations and Customer Loyalty. Psychology and Marketing 21(5): 351 -373 .

Zeithaml VA and Bitner M J (2000) Services Marketing: Integrating customer focus across the firm, 2nd ed., Irwin/ McGraw-Hill, Boston, M.A.

Zeithaml VA and Bitner MJ (2003) Services Marketing: Integrating Customer Focus across the Firms. 3 rd Edition, New Delhi: Tata McGraw Hill.

Zeithaml VA, Berry LL and Parasuraman A (1996) The behavioral consequences of service quality. Journal of Marketing, $\mathbf{6 0}$ (2): 31-46.

Zeithaml VA, Bitner MO and Gremler DE (2009) Services Marketing: Integrating Customer Focus across the Firm. New York: Mcgraw-Hill/Irwin. 